\title{
Using market mechanism to stimulate sustainable use of the non-renewable environmental resource (groundwater) in Barind Tract of Bangladesh
}

\author{
Anutosh Das $^{1,2}$, Sumaia Kashem ${ }^{1,3}$, Mahamudul Hasan ${ }^{1}$ \\ ${ }^{1}$ Department of Urban \& Regional Planning, Rajshahi University of Engineering \& Technology, Rajshahi, Bangladesh \\ ${ }^{2}$ Department of Urban Planning and Design, The University of Hong Kong, Hong Kong, People's Republic of China \\ ${ }^{3}$ Institute of Water and Flood Management, Bangladesh University of Engineering \& Technology, Bangladesh
}

\begin{abstract}
Agriculture, the main economic driver of Barind Tract, is highly dependent on groundwater for surface water paucity in the area. Notwithstanding, farmers use water capriciously due to its low price that makes a substantial drop in the water table. In this context, the research attempts to determine a market-based water pricing mechanism to encourage an optimal use of the scarce non-renewable resource. Required data was collected by questionnaire survey, Focus Group Discussion (FGD), Contingent Valuation Method, expert-opinion survey and subsequent literature works. The results reveal that depletion level has arrived at 20, 11, 7.5 feet in high, mid and low tract respectively over the last 22 years, which results in a number of economic-environmental externalities in the area. The research monetarily evaluated the cost of externalities and incorporated it with the marginal cost of extraction to increase efficiency of an existing pricing system. Regarding human reaction to price elasticity, the new price can be a reliable attempt to reduce an overconsumption pattern of water. Quantity of consumed water can be reduced to $14190.4 \mathrm{~m}^{3}, 17759.59 \mathrm{~m}^{3}$ and $38510.6 \mathrm{~m}^{3}$ in a year in high, mid and low tract area respectively with its implementation. The research will serve as an initiative to conserve the valuable groundwater resource for future generations by managing consumer practice.
\end{abstract}

KEYWORDS Groundwater; non-renewable resource; cost of resource degradation externalities; pricing mechanism; consumer practice CONTACT Anutosh Das anutosh@connect.hku.hk

Received 10 April 2020

\section{Acronyms}

Bigha A land measurement unit very common in Bangladesh which is equivalent to 14,400 square feet

BDT/ TK The currency used in Bangladesh

BMDA Barind Multipurpose Development Authority, the Bangladesh government development authority under the Ministry of Agriculture responsible for the development of Barind tract

Upazila An administrative region in Bangladesh, functions as sub-units of districts

DAE Department of Agricultural Extension, an organisation works to develop opportunity plan for facilitating agricultural growth and development

Kharif 1 Farmers cultivate a variety of crops in their land in different seasons, Kharif 1 is one of the seasons. The duration of the season is from mid-march to mid-July

Kharif 2 Kharif 2 is another season for the cropcultivation in Bangladesh agricultural system. The duration of the season is from mid-July to mid-November.

Rabi Rabi is the last season for the crop- cultivation in Bangladesh agricultural system. The duration of the season is from mid-November to mid-March

\section{Introduction}

In 1978-79, a widespread drought reduced rice production by 2 million tons and directly affected $42 \%$ of cultivated lands and $44 \%$ of the population in Bangladesh. Not only in that year but also 19 more times over the last 50 years, drought has caused dreadful damage to the farm sector directly (Banglapedia, 2014). The hot and humid climate with low rainfall and low moisture in the soil causes surface water paucity which makes people fully reliant on groundwater for survival of the farm sector. A significant change has been observed in the dependency of surface water to groundwater from 1970 onwards for irrigation purpose (UNDP, 1982) to overcome the loss of crop damage caused by drought. About one fourth of the world's irrigated land deliveres groundwater, among which $75 \%$ of these lands are in Asia (Rahman and Mahbub, 2012; Shamsudduha et al, 2011). Availability of groundwater for irrigation has contributed to manifold increases in crop productivity of Bangladesh. But from another point of view, it has become free access common pool resource because of its extraction by many users at a time and that eventually leads to the tragedy of commons. The unfortunate fact that the communities share these common pool resources is paving the way for their destruction. It is because whenever a product is free or undervalued, it promotes misuse rather than efficiency of use (Hardin, 1968). Moreover, the uncontrolled use of water has been accelareted due to the irrigation maintained by subsidised electricity in the 
farm sector which in turn leads to a severe deterioration in the valuable environmental resource (Kumar et al., 2007; Rahman and Mahbub, 2012). In that case, market can be an effective means of shielding environment by endorsing efficient market-based incentives. Water pricing has been indicated as an effective market-based incentive for improving water distribution and reducing water consumption (Bosworth et al., 2002; Easter and Liu, 2005; Johansson et al., 2002; Perry, 2001; World Bank, 2006). But in the real field, the conventional water tariff system, which is based only on the marginal cost of extraction, supports very negligible prices. The existing policy of setting a low price for water can not generate proper incentives to reduce water consumption (Ahmad, 2000), while the main goals of the irrigation regulatory and pricing systems should be equity and efficiency (Seagraves and Easter, 1983). Multiple researchers have also ensured the positive effect of an increase in the water price on the implementation of water conserving irrigation technologies by farmers (Afroz, 2010; Caswell and Zilberman; 1985, Caswell and Zilberman, 1986; Kanazawa, 1994). To achieve efficient and equitable use and conservation of water resources, it is necessary to treat water not only as economic goods but also as social goods (Dinar and Saleth, 2005). But this is not happening in reality. As a result, the dynamic inefficiency makes groundwater, scarcer day by day as the stock is not unlimited.

Particularly in a northwestern region in Bangladesh as Barind Tract, the geographical condition is not conducive to agricultural production because of low rainfall, warm climate and more specifically drought. Water bodies in this area are going dry, river beds are being filled with sand, and water flow in the river is decreasing during the dry season (Shahid 2011; Shahid and Behrawan 2008). People are highly reliant on groundwater which is abstracted by the BMDA. A BADC survey (2002) reports that the contribution of groundwater increased from $41 \%$ in $1982-83$ to $75 \%$ in $2001-02$. It reached $77 \%$ in the next two years. But an increasing irrigation demand arising from the overwhelming population, food insecurity, and uncontrolled water withdrawal and below average rainfall is putting unprecedented pressure on groundwater that triggered the water level to fall to the extent of not getting fully replenished in the recharge season (Shahid and Hazarika, 2010). As a result, the groundwater table in the northwestern region is gradually declining (Ahmeduzzaman et al., 2012; Aziz et al., 2015; PRIO, 2012; Rahman and Mahabub, 2012) and the rate of falling water table has increased to 2 feet a year in the Barind area. The overuse of groundwater will therefore remain crucial to sustaining an agricultural growth to meet Bangladesh's future food supplies. (Qureshi et al., 2015). Unfortunately, the farmers are using groundwater more than required due to its low price. The existing water price does not even consider the externalities arising from the overuse of water. Therefore, it is imperative to evaluate effective pricing options under scarcity for its sustainable management.

However, literature is not specific enough to evaluate an effective pricing mechanism for the proper use of the ground water in the Barind region of Bangladesh. The study aims to document the current groundwater depletion status in this region and portray an efficient water pricing mechanism that not only contributes to the agricultural sector's development for marginal labour but also preserves a right for future generations by reducing the overuse. It would also assist to investigate the relationship between costs, prices and consumption of water how the modifications of price can be made to ensure sustainable consumption.

\section{Literature review}

The scarcity of water which in turn results in drought has been one of the outrageous calamities in the northwestern region of Bangladesh. 12 moderate to extreme agricultural droughts were experienced in the years 1972, 1975, 1979, 1982, 1986, 1989, 1992, 1994, 2003, 2005, 2009 and 2010, and the frequency of drought is increasing gradually (Rahman et al., 2017). The authors marked groundwater irrigation as vulnerable to drought for the reduction in soil moisture at an excessive level. As the largest user of groundwater for agricultural irrigation, an increasing demand for water results in groundwater drought in arid and semi-arid regions in South Asia. The long term and continuous extraction of water exceeds aquifer recharge and produces declining trends in aquifer storage and hydraulic head (Zektser et al., 2005). Moreover, Adhikary et al. (2013) have also tried to find the reason for drought in the northwestern region. For this reason, the study used the Cumulative Deficit (CD) approach to evaluate drought severity and $C D$ values were interpolated in ArcGIS to prepare groundwater (GW) drought maps while the Standardized Precipitation Index (SPI) method computed meteorological drought. The study specifies that a significant declination is observed in GW table from the hydrographs for excessive withdrawals which are mainly responsible for GW drought in northwestern region in Bangladesh. The deficiency of rainfall may turn the GW drought into meteorological drought but the first step of it is the mass withdrawal of GW. However, Zahid and Ahmed (2006) portrayed the causes of withdrawals of GW in the Barind region in their research by a benefitcost ratio analysis. To overcome the problem of ambivalent agricultural section of this region, the Barind Integrated Area Development Project (BIADP) has been undertaken by BMDA since 1986 which ensures that GW based irrigation through installation of Deep Tube Wells (DTWs). DTWs manifested yield of Boro rice increased from $43 \%$ to $120 \%$ and other cropping intensity increased $59 \%$ in the past ten years. Nevertheless, the extensive use for irrigation is claimed to be responsible for a continuous decline 
in water level which demands urgent management of groundwater resources. Qureshi et al. (2015) also point out that the water policy in Bangladesh focuses on development rather than management of resources. Though increased groundwater accessibility accelerates crop production but in the long term it is accountable for degrading the environment. Mass abstraction of groundwater causes many externalities such as excessive drawdown in intensively irrigated areas, depletion of groundwater level, etc. However, they emphasised on reducing the stress on groundwater before the problem became either insolvable or too costly to remediate. Many researchers have suggested that water pricing can be an important incentive to ensure sustainable consumption (Bosworth et al., 2002; Easter and Liu, 2005; Johansson et al., 2002; Kemper et al., 2006; Perry, 2001). Bazza and Ahmad (2002) have also referred it as a vital instrument for ensuring improved conservation and quality preservation in their study. According to the Fourth Principle of the 1992 Dublin Statements, setting up 'efficient' water pricing policy by treating water as economic goods is a prerequisite to achieving equitable use of water resources. Underpricing irrigation water can result in a waste of water, inadequate cost recovery, improper operation and maintenance (O\&M) and environmental degradation etc. (Samal and Kolanu, 2004). Ahmad (2000) also elucidates that the policy or setting a low price sends wrong signals to the producer and consumers about the true scarcity value of resources which often leads to overconsumption of commodities and results in resource degradation. Pricing water consumption correctly can be an imperative means for managing their wrong practice. Through increasing water prices in accordance with the established rules of economic theory (Rogersa 2002), reduction in the waste of water can be attained. Thus, an increase in water price can be an important incentive for sustainable use of irrigation water.

The undervaluation of the valuable resource groundwater prevails also in Bangladesh (Kemper et al., 2004). Nevertheless, the farm sector, which is a major economic sector of this country, depends on GW. The existing price only covers installation and O\&M costs but rarely the costs of externalities. Thus, paying a part of the cost, the exploiter receives all the benefits of groundwater that in turn is accelerating misuse and exhausting the GW stock. The authors emphasise economic consideration to manage the current practice of consumption and promote more efficient use of resources. The research highlights people's reaction to price incentives (when prices are high, fewer resources will be consumed) and proposes incorporating the cost of degradation externalities into price for efficient allocation over time. Reddy (2005) measured costs of groundwater depletion externalities in his study on Andhra Pradesh, India for the first time. The study endeavoured to estimate the costs of groundwater over exploitation and signifies how groundwater exploitation in Andhra Pradesh, India caused economic losses to individual farmers in addition to ecological degradation. He demonstrated that costs of degradation externalities were disproportionately borne by these farmers as the cost was measured on the basis of classification of farmers. Finally, the research concludes by recommending some policy issues to reduce the degradation without focusing on suggesting an efficient water pricing mechanism.

Corresponding the above literature, the present research attempts to resolve the shortcomings of an existing pricing system. It differs from other studies on the consideration of the cost of externalities associated with over-extraction of groundwater for irrigational use in order to determine an efficient pricing mechanism.

\section{Research area and methodology}

The prevailing uncongenial and inapt factors for surface water availability such as geology, rainfall, soil properties led to greater dependency on GW for irrigation $(90-95 \%)$ in the northwestern region of Bangladesh.

\section{Barind Tract, Rajshahi Division}

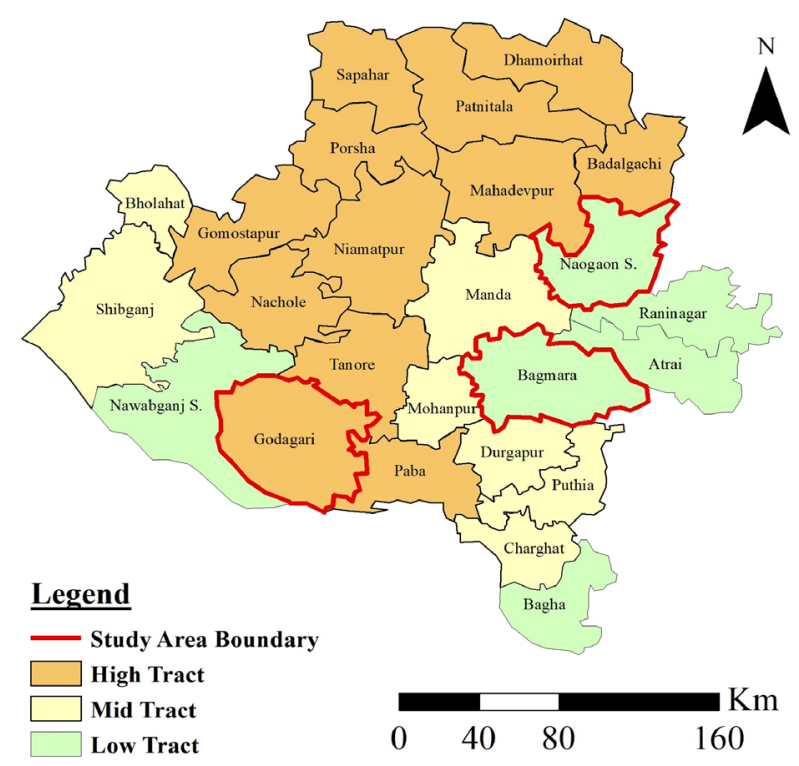

Figure 1. Map of the studied area (Adapted from BMDA, 2018a).

Based on elevation, BMDA has classified the total Barind Tract into three classes: High, Mid and Low tract. Among them one upazila is randomly selected from each tract for an experimental approach. They are godagari (High tract) and partial bagmara (Mid tract) upazila of Rajshahi District and Naogaon sadar upazila (Low tract) of Naogaon District.

Secondary data was collected from BMDA, and Department of Agricultural Extension (DAE) to obtain 
proper knowledge about the current groundwater status and water pricing mechanism. It includes yearly database of groundwater table, total cultivable land, net irrigated area, number of wells for the time period (1996-2017), and data regarding an existing water pricing mechanism, etc. Moreover, the major objective of the study is to propose an effective pricing mechanism that is basically based on literature review and field data. After an extensive literature review, a reconnaissance survey was conducted to identify the externalities of mass GW abstraction in the context of Bangladesh. The decline in the paddy area, crop shifting pattern, and the investment in lifting wells in to lower level of ground due to depletion, etc. are the externalities considered in the study. Several field visits were paid to the three selected upazila for a questionnaire survey with 120 samples including the pump owner, farmers, water buyers who were directly or indirectly involved in water use for irrigation. Additionally, three FGDs of 8-10 members is carried out in three different upazila to have clear concept about some issues such as shifting in crop pattern, net benefits of the farmers, types of major crops, and changes in crop types during the period, etc. After the price has been set out through the proposed pricing mechanism, the Delphi method was used for obtaining expert opinions about the feasibility of the model. Four experts were involved: two economists, one sociologist, and one agricultural personnel. At last, the Contingent Valuation Method (CVM) was conducted with 50 samples to stimulate 'Willingness to Pay' extra amount for water to reduce depletion.

\section{Current groundwater status in studied area}

To meet the demand for surface water, use of groundwater is increasing in this region that has made the water table gradually fall in the northwestern region over the years (Ahmeduzzaman et al, 2012; Aziz et al., 2015; PRIO, 2012: Rahman and Mahabub, 2012). The decline in ground water level was measured by a hypothesis test. The GW level data was used as a sample to derive descriptive statistics of mean, standard deviation using the value for the periods of 1996 to 2017 . According to the common consideration for using a normal distribution in testing hypotheses, one-tailed ' $\mathrm{t}$ ' distribution formula was used in the study for having a sample size (22 years) under 30 with $95 \%$ confidence interval. The 't statistics' analyses of data of water level of each of the upazila separately show that the average water level varies from area to area on the basis of high, medium and low tracts but in all cases depletion is common. That groundwater level in the studied area depleting in an accelerating rate over the time can be revealed by the depletion trend of maximum and minimum water level in the last 22 years in each zone. The water level varies from 46 feet to 80 feet in high tract Godagari area, from $28.36 \mathrm{ft}$. to $12.15 \mathrm{ft}$. in mid tract Bagmara area, and from 14 to 25 feet only in low tract Naogaon Sadar area.

However, from the climatic point of view, the declination extent was measured on the basis of three seasons, 1) the hot summer season from March to May, 2) the wet monsoon season from June to October and 3) the dry winter season from November to February (Shahid \& Hazarika, 2009). Table 1 portrays that the declination level is not indifferent in all seasons. A higher fluctuation was observed in the dry winter season in a high tract region but in the hot summer season in mid and low regions.

\section{New pricing mechanism to reduce depletion}

The proposed pricing mechanism focuses on incorporating the cost of resource degradation externalities into the price for water to ensure an optimal use of groundwater the scarce environmental resource. It can be depicted as:

Price per hour $=\mathrm{MEC}+\mathrm{CRDE}=$ Depreciation value of IC + O\&M cost + CRDE.

Where, $\mathrm{IC}=$ Installation Cost of DTW, O\&M Cost $=$ Operation and Maintenance Cost, and $\mathrm{CRDE}=$ Cost of Resource Degradation Externalities.

The installation cost of DTW including all the associated costs during installation (price of a pump set, pipe, filter and other equipment, labour cost, cost of

Table 1. Season-wise fluctuation rate of average water level (1996-2017) (BMDA, 2018b).

\begin{tabular}{|c|c|c|c|c|c|c|c|c|c|}
\hline Studied Area & \multicolumn{3}{|c|}{ Godagari } & \multicolumn{3}{c|}{ Bagmara } & \multicolumn{2}{c|}{ Naogaon Sadar } \\
\hline Season & Summer & Monsoon & Winter & Summer & Monsoon & Winter & Summer & Monsoon & Winter \\
\hline $\begin{array}{c}\text { Ground water level } \\
\text { in 1996 }\end{array}$ & 68.03 & 47.13 & 42.25 & 26.44 & 7.37 & 15.19 & 23.833 & 11.35 & 15.27 \\
\hline $\begin{array}{c}\text { Ground water level } \\
\text { in 2017 }\end{array}$ & 74.75 & 70.02 & 68.17 & 45.54 & 15.54 & 23.93 & 31.276 & 17.21 & 20.25 \\
\hline $\begin{array}{c}\text { Differences in feet } \\
\text { Time period (year) }\end{array}$ & 6.72 & 22.88 & 25.92 & 19.09 & 8.17 & 8.75 & 7.44 & 5.86 & 4.97 \\
\hline $\begin{array}{c}\text { Fluctuation in feet/ } \\
\text { year }\end{array}$ & 0.31 & 1.04 & 1.17 & 0.87 & 0.37 & 0.40 & 0.34 & 0.86 & 0.226 \\
\hline
\end{tabular}


electricity connection) is calculated using the formula of the present value of an annuity.

$$
\text { Annualised cost per year, } A={ }^{P V A n} \times r(1+r)^{n} /(1+r)^{n}-1 \text {, }
$$

$$
\operatorname{PVA} n=\text { Installation cost }- \text { Resale value after expiry. }
$$

The priority was given to the maximum used pump and housing head of each tract for calculation of depreciation value. It was calculated with $10 \%$ discounting rate and $\mathrm{n}$ was considered an average economic life of a DTW (30 years) (Amin, 2007). The annualised depreciation cost is divided by average command area of a DTW and the total hours of discharge (in year) to calculate the unit depreciation cost.

The O\&M cost is calculated as,

$$
\begin{aligned}
& \text { O\&M cost }=\text { Fuel Cost }+ \text { Salary of th officials }+ \text { Maintenance Cost of DTW }+ \\
& \text { Salary of dealer and operator of DTW. }
\end{aligned}
$$

The information was collected from the BMDA office to find out their actual cost to run a DTW for one hour. However, depending on the fuel cost, the O\&M cost varies according to tract. For example, DTW of the $21 \mathrm{~m}$ head consumes 17 units of electricity per hour (for mid and low tract) where, in case of high tract, the greater head consumes 20 units of electricity.

Groundwater table depletes because the water is extracted beyond the optimum recharge level. The effect of this continuous over-extraction results in various economic and environmental externalities such as an increase in pumping costs, costs of deepening wells and pumps, shifting of agricultural patterns, etc. (Baniasadi et al., 2016; 2019). The costs of externalities can be evaluated as a sum of direct and indirect costs occurring from this over-extraction of resources. Direct cost is a one-time cost to lift the pump and install it to lower section. But it will increase with time along with the number of wells dried and need to be lifted. Indirect costs are incurred due to decline in the paddy area and the crop shifting pattern due to water scarcity (Reddy, 2014). The cost will increase with the depletion of water level. The CRDE was monetarily evaluated using the following procedures:

$$
\text { Cost of Resource Degradation Externalities = Direct Cost }+ \text { Indirect Cost , (5) }
$$$$
\text { Direct Cost }=\frac{\text { No of well lifted in last } t \text { 't time* lifting cost }}{\text { Total cultivated area in bigha *total irrigation hour to cover unitbigha in year }} \text {, }
$$

$$
\text { Indirect Cost }=\frac{\text { Average decline in Paddy Area } * \text { differential net return }}{\text { Total cultivated area in bigha } * \text { total irrigation hour to cover unit bigha in year }}
$$

Due to data unavailability, the ' $t$ ' time period was considered as 17 years (from 2001-2017). And the differential net return was estimated by subtracting the net return of the crops that replaced paddy from the net return from paddy. The net return of the crops were calculated by weighted average of profit on the basis of proportion of area under crop. The decline in the paddy area was used to estimate the losses from crop shifting patterns (Reddy, 2014). All the cost were calculated in BDT/hour unit. The zone-wise water price was estimated using the above mentioned formula separately for each zone.

Table 2. Estimated price using proposed mechanism.

$\begin{array}{ccc}\text { Zone } & \begin{array}{c}\text { Existing price } \\ \text { (BDT/hour) }\end{array} & \begin{array}{c}\text { Proposed price } \\ \text { (BDT/hour) }\end{array} \\ \text { High tract } & 148 & 161 \\ \text { Mid tract } & 125 & 142.5 \\ \text { Low tract } & 125 & 139\end{array}$

(Source: Author's Calculation, 2018)

\section{Model validation and calibration}

The model can be validated and calibrated from four perspectives such as the economic point of view, the views of consumers and producers, and in social and environmental context.

\subsection{From the economic point of view}

Under this mechanism, the price has become slightly higher than the existing one. The small increment in price of GW saves several hours of consumption in all tracts of the studied area. Due to GW layer depletion over time, it needs to suction water from deeper layers than earlier. From the economic point of view, and the consumption decreases with the increasing costs of groundwater with time; hence, the demand curve is sloping downward. The proposed price will reduce consumption time for 185 , 117, 216 hours in a year in high, mid and low tract zones respectively. However, it should be noted that the reduction in consumption time is not fixed in all similar tract because it is governed by the demand function of consumption time in any area. It is already stated that this study focuses on a maximum used pump of any tract from which the quantity of consumed water is measured. The maximum suction power of pumps in high, mid and low tract zones are $0.75,1.5,1.75$ cusec respectively. Figure 2 shows that the quantity of consumed water will be reduced to $14190.4 \mathrm{~m}^{3}$, $17759.59 \mathrm{~m}^{3}$ and $38510.6 \mathrm{~m}^{3}$ in a year in high, mid and low tract areas respectively with the execution of the proposed price. 
(a)

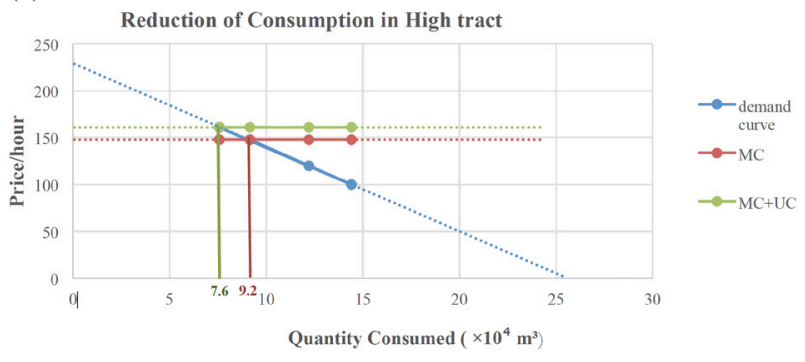

(b)

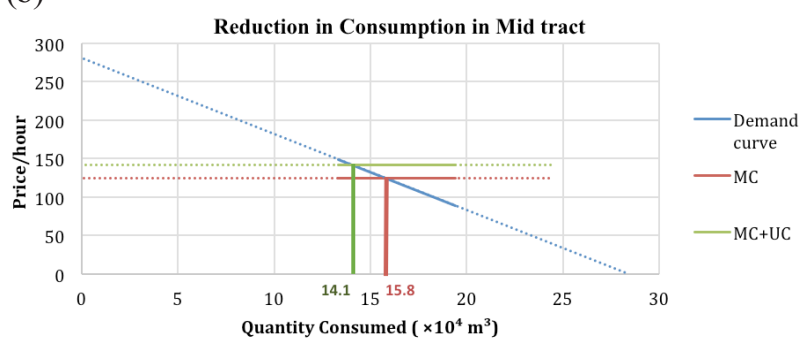

(c)

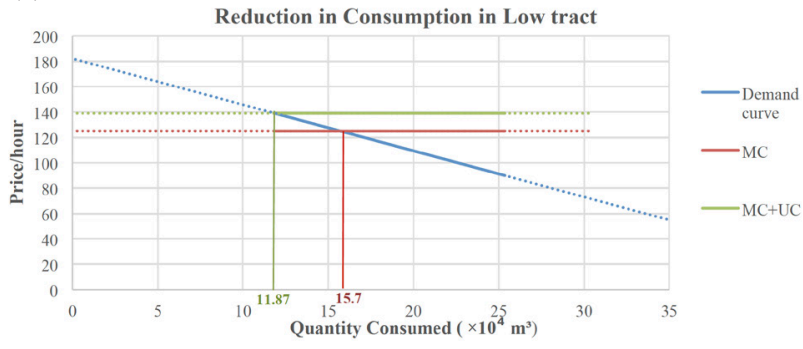

Figure 2. Reduction in GW consumption (2a, 2b, 2c indicates high, mid and low tract area).

(Source: Author's Calculation, 2018)

It can be noted from agricultural professionals that the less consumption of irrigation water does not reduce the profit if modern agriculture applies. A lack of proper knowledge is one of the major reasons for misuse of water in the Barind Area. In Bangladesh, Boro rice cultivation is still largely done in a traditional way by applying flood irrigation: 'the more water, the more cultivation'. But keeping Boro rice fields moist but not getting them flooded for 3 or 4 days do not reduce yields. The choice of appropriate crop is also a requisite for sustainable agriculture.
Moreover, in mainstream Economics, with an increase in price of any product, the consumer surplus reduces and producer surplus increases. In this study, in trade of GW, consumers, mainly farmers, are water users, and the producer is water supplier, BMDA. Higher GW prices initiated by the proposed mechanism do not necessarily lead to a net loss in economic welfare; they rather reduce the use of GW and shift resources from GW consumers to GW producer because of reduction in consumer surplus and increase in producer surplus. In trade of nonrenewable environmental goods, however, the producer surplus need not always increase with establishing a higher price. In fact, the higher price results in social welfare gain that discourages the misuse of non-renewable resources through setting up higher prices (Wiser et al., 2004). With an implementation of the proposed prices, the consumer surplus will reduce from 3.91 million Tk. to 2.73 million Tk. The producer surplus will reduce up to 1.38 million Tk. In return, it reduces up to $14190.4 \mathrm{~m} 3$ water consumption in high tract of which environmental value is higher than this small amount of producer surplus. Thus, the total surplus (sum of the consumer surplus and producer surplus) increases if the environmental benefit value of reduction of misuse is added to it. Likely, consumer surplus decreases up to 2.6 and 2.15 million Tk. in mid and low tract zones respectively.

\subsection{From consumers' point of view}

Farmers cultivate a variety of crops in their lands in different seasons such as kharif 1 (mid-March to midJuly), kharif 2 (mid-July to mid-November) and rabi season (mid-November to mid-March) in the Barind Region. They cultivate Aus rice in kharif 1 season and Amon rice in kharif 2 season. The variation usually occurs in the Rabi season due to a variety of crop options. Though farmers are shifting into different rabi crops such as maize, potatoes, wheat because a high demand for water for Boro rice results in a high cost of Boro rice cultivation. Notwithstanding paddy (kharif as well as rabi) is a main crop in Bangladesh and the percentage of Boro cultivation is higher than other rabi crops'. However, as the amount of water required varies from crop to crop, the price increment has a substantial impact on the irrigation cost. It has increased with the increment of the existing price through the

Table 3. Increasing effects of proposed price on irrigation costs.

\begin{tabular}{|c|c|c|c|c|c|c|}
\hline \multirow{2}{*}{ Criteria } & \multicolumn{2}{|c|}{ High tract } & \multicolumn{2}{c|}{ Mid tract } & \multicolumn{2}{c|}{ Low tract } \\
\cline { 2 - 7 } & $\begin{array}{c}\text { Existing water } \\
\text { cost }\end{array}$ & $\begin{array}{c}\text { Proposed water } \\
\text { cost }\end{array}$ & $\begin{array}{c}\text { Existing water } \\
\text { cost }\end{array}$ & $\begin{array}{c}\text { Proposed water } \\
\text { cost }\end{array}$ & $\begin{array}{c}\text { Existing water } \\
\text { cost }\end{array}$ & $\begin{array}{c}\text { Proposed water } \\
\text { cost }\end{array}$ \\
\hline Rice & 2886 & 3120 & 1625 & 1852.5 & 1625 & 1807 \\
\hline Rice and potato & 1665 & 1800 & 937.5 & 1068.75 & 937.5 & 1042.5 \\
\hline Rice and wheat & 1665 & 1800 & 937.5 & 1068.75 & 937.5 & 1042.5 \\
\hline Rice and maize & 1887 & 2040 & 1062.5 & 1211.25 & 1062.5 & 1181.5 \\
\hline
\end{tabular}

(Source: Author's Calculation, 2018) 
Table 4. Reduction in profit of farmers.

\begin{tabular}{|c|c|c|c|c|c|c|}
\hline \multirow{2}{*}{ Crops cultivated } & \multicolumn{2}{|c|}{ High tract } & \multicolumn{2}{c|}{ Mid tract } & \multicolumn{2}{c|}{ Low tract } \\
\cline { 2 - 7 } & $\begin{array}{c}\text { Earlier profit } \\
\text { (BDT) }\end{array}$ & $\begin{array}{c}\text { Present profit } \\
\text { (BDT) }\end{array}$ & $\begin{array}{c}\text { Earlier profit } \\
\text { (BDT) }\end{array}$ & $\begin{array}{c}\text { Present profit } \\
\text { (BDT) }\end{array}$ & $\begin{array}{c}\text { Earlier profit } \\
\text { (BDT) }\end{array}$ & $\begin{array}{c}\text { Present profit } \\
(\mathrm{BDT})\end{array}$ \\
\hline Rice & 22,000 & 21,766 & 24,000 & $24,227.50$ & 28,000 & 27,818 \\
\hline Rice and potato & 28,400 & 28,265 & 30,700 & $30,831.25$ & 36,200 & 36,095 \\
\hline Rice and wheat & 23,100 & 22,965 & 25,700 & $25,831.25$ & 32,200 & 32,095 \\
\hline Rice and maize & 24,600 & 24,447 & 26,700 & $26,848.75$ & 29,200 & 29,081 \\
\hline
\end{tabular}

(Source: Author's Calculation, 2018)

proposed mechanism in every zone. The irrigation cost (per Bigha) is calculated by multiplying irrigation frequency with the cost per irrigation. The increase in the irrigation cost is epitomised through the comparison between existing irrigation cost and the proposed irrigation cost for high, mid and low tract zones.

As the cost increased in some amount for the proposed pricing mechanism, the profit of the farmers was reduced with the cost increment. The farmers' profitability is inversely related with the cost of water. The comparison in the profit margin per bigha for the existing and the proposed mechanism is shown in Table 4.

The farmers' profitability is also dependent on their cultivated crops due to crop-wise different water requirements. There net profit of cultivating other rabi crops is higher than cultivating rice in all season in all of the tract. Hence the crop shifting from traditional rice to rabi crops does not result in the loss of farmers' incomes.

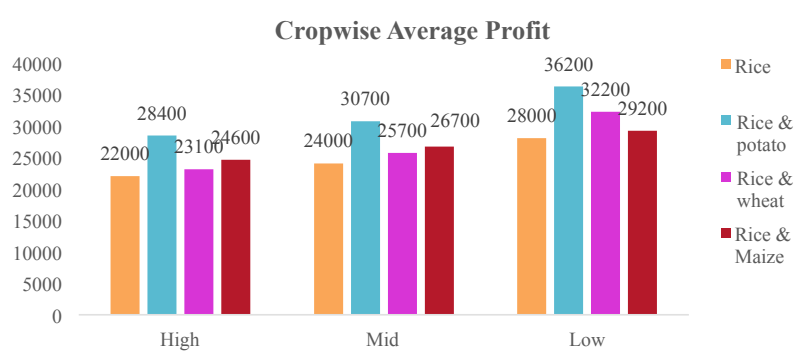

Figure 3. Crop-wise average profits.

(Source: Author's Calculation, 2018)

Furthermore, the reduction in profit is not very high for the farmers working in one bigha land comparing with their net profit. So, the farmers will not be reluctant to pay the increased amount if their profit always meets the margin described here. The majority of the respondents $(72 \%)$ stated that they were willing to pay extra amounts for the preservation of groundwater. The marked reasons behind the reluctance are not getting actual price in the market $(54 \%)$, their doubt on the reliability of service (34\%), etc. While the farmers who has agreed to pay the additional increased groundwater price (i.e., environmental cost of groundwater) gave reasons such as the price of private semi deep well was much higher than BMDA provided
DTW (32\%), their dependency on groundwater (68\%). However, the major drawback of the CVM method is that people tended to overestimate the willingness to pay (WTP) amount especially if they knew that they are not bound to pay the stated amount in reality.

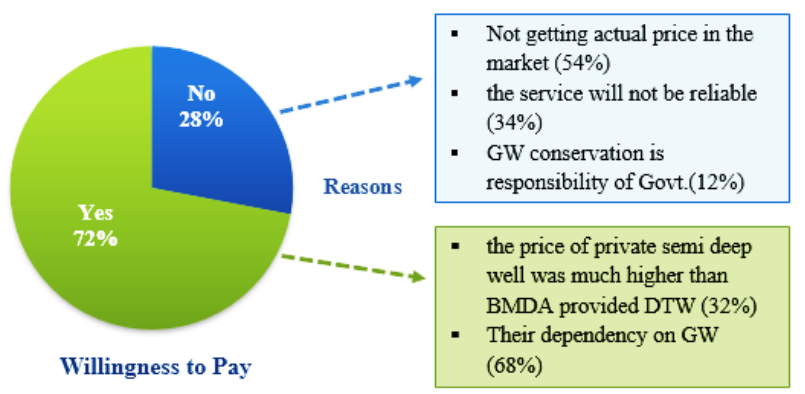

Figure 4. Willingness to pay (WTP) for increased groundwater pricing and the reasons behind the decision. (Source: Author's Calculation, 2018)

\subsection{From producers' point of view}

Though the increased cost of water has a less impact on the individual farmer's profitability, it has a great impact on the revenue that the government can earn from the price increment. The gross profit for each crop can be calculated by multiplying the total cultivated lands under the crop by the irrigation frequency and the price increment per irrigation. However, the total gross revenue varies from one tract to another because of the varying cultivated lands for different regions and the cost incurred differently in high, mid and low areas. For each tract, the total gross profit for all the crops add an exorbitant amount of revenue in the government account. For instance, it brings about US $\$ 0.33$ million in a year from high tract Godagari Upazilla. From mid and low tract, the government will earn approximately US $\$ 0.35$ million and US $\$ 0.13$ million respectively. For present and uncontrolled consumption, when the water table depletes in such a level, the marginal cost of extraction will be greater than the benefit. Then an exploration of alternative solution will be necessary. Regarding this, the opportunity cost must be invested to create solutions and reduce the pressure on groundwater. Some of the recommendations are explored from the Expert Opinion Survey: increasing rainwater storage capacity, provision of 
subsidies to reach a market equilibrium, developing storage capacity of surface water, and green technology to develop the surface water irrigation, etc.

\subsection{From the view of social and environmental context}

The proposed mechanism not only influences the economic sector but also has a noteworthy impact on social context in a broader term. The amount of increment will not matter at individual level while it brings a gross revenue on the account of government. On the contrary, crop shifting towards cultivation of rabi crops does not cause net loss in a water scarce region. Earning more profits with less water is a beneficial approach. The less water extraction, the less depletion of the GW layer, and the less scarcity of water. It basically decrease the cost of externalities incurred due to GW depletion. It will also benefit the long term sustainability of agriculture. If the depletion continues, there will be no water in the future. Consequently, the backbone of the country, i.e. the agricultural sector, will collapse. Therefore, the implementation of the pricing mechanism may cause a little decline in profit, but in the long run it will support farmers a great deal. With the lowering of water table, the cost of extraction rises, which in future will be a burden upon the farmers. Moreover, it is necessary to raise an awareness of how applying modern agriculture will reduce their water use without undermining crop production.

\section{Conclusion}

In the Barind region, groundwater declination is not only happening due to deficit of rainfall, but also for overexploitation of this resource. An increasing demand for groundwater for agriculture-based subsidised projects is one of the major reasons for this overconsumption. Considering this, the primary objective of the research is to analyse the current GW depletion status and on this basis proposition of a smart pricing mechanism for ensuring sustainable water consumption. The level of GW reduced from 46 feet to 80 feet in high tract Godagari area, from 12.15 feet to 28.36 feet in mid tract Bagmara area, and from 14 feet to 25 feet only in low tract Naogaon Sadar. In view of this high exhaustion the research proposes a new pricing mechanism. The uniqueness of the mechanism is to incorporate the cost of externalities due to GW depletion. The new price applying to the mechanism is slightly higher than an existing one. Though the cost of the ground water increased slightly and so the farmers' profitability was reduced in some cases, the farmers and the country as a whole will gain from the price increment in the long run. For instance, with the implementation of the proposed price, the quantity of consumed water will be reduced to $14190.4 \mathrm{~m}^{3}, 17759.59 \mathrm{~m}^{3}$ and $38510.6 \mathrm{~m}^{3}$ in a year in high, mid and low tract areas respectively. Moreover, the government will earn approximately US\$0.33 million, US\$0.35 million and US\$0.13 million from high, mid and low tracts respectively. Furthermore, this gain can assist in creating alternative solutions and reduce the pressure on the supply of groundwater. Finally, the research offers a pricing mechanism which can be functional in any arid area like the Barind region. It is expected that this research work will be very helpful for the management of the most valuable environmental resource (groundwater) by controlling the unsustainable and inconsiderate consumption.

\section{Notes on Contributors}

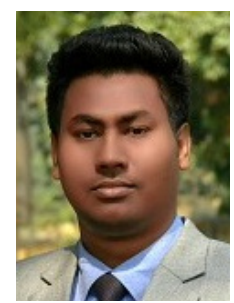

Mr Anutosh Das is an Urban Planner by passion and profession who wishes to comprehend the interplay between haphazard urban growth and environmental sustainability of cities from a global, inclusive standpoint. Mr Das has been a faculty member in the Department of Urban \& Regional Planning at Rajshahi University of Engineering \& Technology (RUET), Bangladesh since 2016. He is a graduate in Urban Planning from Bangladesh University of Engineering and Technology (BUET) and has earned M.Sc. degree in Urban Planning from The University of Hong Kong (HKU) as an ADB-JSP Fellow. He is an Affiliated Member of the Royal Town Planning Institute (RTPI) as well as Associate Member of the Bangladesh Institute of Planners (BIP). He is an Editorial Board Member of the Planning and Development, Journal of the Hong Kong Institute of Planners (HKIP) and Member of the exquisite Regional Science Association International (RSAI). As an interdisciplinary researcher, he is predominantly interested in effecting positive change in cities and urban environments globally. Mr Das's research interests are diverse, but all revolve around Climate Change Vulnerability Analysis, Mitigation and Adaptation Planning with a core focus on Green Growth, The Economics of Climate Change and Regional Econometric Analysis. As of April 2021, his related research has resulted in more than 50 profound publications in different peer-reviewed multidisciplinary journals, conference proceedings and policy papers. His profound academic and professional background focuses on the sound assimilation of the global economic and socio-political context in addressing evidence-based solutions for Development, Natural Resource management, Environment Conflict \& Challenge Management utilizing Economic Tools and Policy Instruments for mainstreaming governance issues as an adaptive measure toward global climate change. 


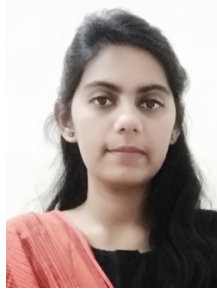

Ms Sumaia Kashem is an Urban Planner with a vision of a planned Bangladesh. She completed her undergraduate study in Urban and Regional Planning from Rajshahi University of Engineering and Technology. She is pursuing her MSc in Water Resources Development as a SAWA Fellow at the Institute of Water and Flood Management at Bangladesh University of Engineering and Technology to meet her interest to work in the domain of environmental resource management. She was awarded this fellowship under the "South Asian Water Leadership Program on Climate Change" funded by IDRC, Canada on 1 December 2018. Her research interests mainly include Environmental Planning and Natural Resource Management.

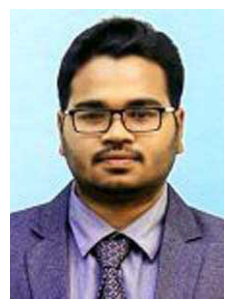

Mr Mahamudul Hasan is a young researcher. He completed his undergraduate degree in Urban and Regional Planning from Rajshahi University of Engineering Technology. To meet his thirst to work in the environmental resource management field, he accomplished his undergraduate thesis on the topic "An Analysis on Efficient Ground Water Pricing in Barind Tract: An Instrument for Groundwater Preservation." Throughout his academic career, he was consistently praised as hard-working by his professors and peers. His main research interests lie in Environmental Planning \& Natural Resource Management.

\section{References}

[1] Adhikary S K, Das S K, Saha G C and Chaki T (2013). Groundwater Drought Assessment for Barind Irrigation Project in Northwestern Bangladesh. In: 20th International Congress on Modelling and Simulation. Adelaide, Australia, pp. 2917-2923.

[2] Afroz U F R (2010). Effect of Pricing in Minor Irrigation on the Water Use by the Farmers. M.Sc. Engineering Thesis. Dhaka: Institute of Water and Flood Management, BUET.

[3] Ahmad M (2000). Water pricing and markets in the Near East: policy issues and options. Water Policy, 2(3), pp. 229-242.

[4] Ahmeduzzaman M, Kar S and Asad A (2012). A study on Ground water fluctuation at barind Area, Rajshahi. International journal of Engineering Research and Application (IJERA, 2(6), pp. 1465-1470.
[5] Aziz M A, Majumder A K , Kabir M S, Hossain M I, Rahman F R, Rahman F and Hosen S. (2015). Groundwater Depletion with Expansion of Irrigation in Barind Tract: A Case Study of Rajshahi District of Bangladesh. International Journal of Geology, Agriculture and Environmental Sciences, 3(1), pp. 2348-2357.

[6] Banglapedia (2014). Barind Tract. [Online]. Available at: <http://en.banglapedia.org/index.php?titleBarind Tract $>$. [Accessed on July 29, 2018]

[7] Bazza M and M Ahmad (2002). A Comparative Assessment of Links Between Irrigation Water Pricing and Irrigation Performance in the Near East. In: Conference on Irrigation Water Policy: Micro and Macro Consideration. Morocco, pp. 1-25

[8] BMDA (2018a). Classification of Barind Tract Service Area according to Elevation. [document]. Barind Multipurpose Development Authority.

[9] BMDA (2018b). Static Groundwater Level Data (1996-2017). [Online]. Available at: <http://www. bmda.gov.bd/site/page/bd61979a-0ab0-4919-881868f8d3be7d47/>. [Accessed on 11 April, 2018].

[10] Bosworth B, Cornish G, Perry C J and Steenbergen F (2002). Water Charging in Irrigated Agriculture; Lessons from the Literature. Wallingford.

[11] Caswell M F and Zilberman D (1985). The Choices of Irrigation Technologies in California. American Journal of Agricultural Economics, 67 (2), pp. 223234.

[12] Caswell M F and Zilbermen D (1986). The Effects of Well Depth and Land Quality on the Choice of Irrigation Technology. American Journal of Agricultural Economics, 68 (4), pp. 798-811.

[13] Dewett K K (1997). Modern Economic Theory. S Chand and Company Limited. India.

[14] Dinar A and Saleth R M (2005). Issues in water pricing reforms: from getting correct prices to setting appropriate institutions. Cheltenham, UK. International Yearbook of Environmental and Resource economics.

[15] Easter K W and Liu Y (2005). Cost recovery and water pricing for irrigation and drainage projects. Washington, DC: World Bank.

[16] Hardin G (1968). The Tragedy of the Commons. Science, 162 (3859), pp. 1243-1248.

[17] Johansson R C, Tsur Y, Roe T L, Doukhali R and Dinar A (2002). Pricing irrigation water: a Review of theory and practice. Water Policy, 4 (2), pp. 173-199.

[18] KANAZAWA M T (1994). WATER SUBSIDIES, WATER TRANSFERS, AND ECONOMIC EFFICIENCY. Contemporary Economic Policy, 12, pp. 112-122.

[19] Kemper K, Foster S, Garduno H and Nanni M (2004). Economic Instruments for Groundwater Management - using incentives to improve sustainability. Washington DC: World Bank. 
[20] Kolås Å, Edelen K, Jahan F, Barkved L, Hoelscher K, Jha H, JBhattacharjee J, Holen S and Miklan J. 2013. Water Scarcity in Bangladesh. Oslo: Peace Research Institute

[21] Perry G J (2001). Polential Role of Water Pricing in Irrigation: the example of India. In: Proceedings of conference on sustainable water management. New Delhi.

[22] Qureshi A S, Ahmed J and Krupnik T J (2015). Groundwater management in Bangladesh: An analysis of problems and Opportunities. Dhaka: USAID.

[23] Rahman M M and Mahbub A Q M (2012). Groundwater Depletion with Expansion of Irrigation in Barind Tract: A Case Study of Tanore Upazila. Journal of Water Resource and Protection, 4, pp. 567575.

[24] Rahman A T M S, Jahan C S, Majumdar Q H, Hosono T and Kamruzzaman M (2017). Drought Analysis and Its Implication in Sustainable Water Resource Management in Barind Area, Bangladesh. Journal of Geological Society of India, 89(1), pp. 47-56.

[25] Reddy V R (2005). Costs of resource depletion externalities: A study of groundwater overexploitation in Andhra Pradesh, India. Environment and Development Economics, 10, pp. 533-556.

[26] Rogersa P, Silva R D and Bhatia R (2002). Water is an economic good: How to use prices to promote equity, efficiency, and sustainability. Water Policy, 4, pp. $1-17$.

[27] Samal C K and Kolanu T (2004). Water pricing and decentralized irrigation management in Andhra Pradesh: schism between objectives and realities. Rural Poverty Reduction through Research for Development.

[28] Seagraves J A and Easter K W (1988). Pricing Irrigation Water in Developing Countries. Journal of the American Water Resource Association, 19(4), pp. 663-672.

[29] Shahid S (2011). Impacts of Climate Change on Irrigation Water Demand in Northwestern Bangladesh. Climatic Change, 105(3-4), pp. 433-453.

[30] Shahid S and M K Hazarika. (2010). Groundwater Droughts in the Northwestern Districts of Bangladesh. Water Resources Management, 24(10), pp. 19892006.

[31] Shamsudduha M, Taylor R G, Ahmed K M, and Zahid A (2011). The Impact of Intensive Groundwater Abstraction on Recharge to a Shallow Regional Aquifer System: Evidence from Bangladesh. Hydrogeology Journal, 19(4), pp. 901-916.

[32] UNDP (1982). Groundwater Survey: The Hydro Geological Conditions of Bangladesh. New York: UNDP.
[33] Zahid A and Ahmed S R U (2006). Groundwater resources development in Bangladesh: Contribution to irrigation for food security and poverty alleviation, International Water Management Institute,

[34] Zektser S, Logaica H and Wolf J T (2005). Environmental impacts of groundwater overdraft: Selected case studies in the Southwestern United States." Environmental geology, 47(3), pp. 396-404. 